\title{
"The impact of digitalization on the economic convergence of the Russian insurance market"
}

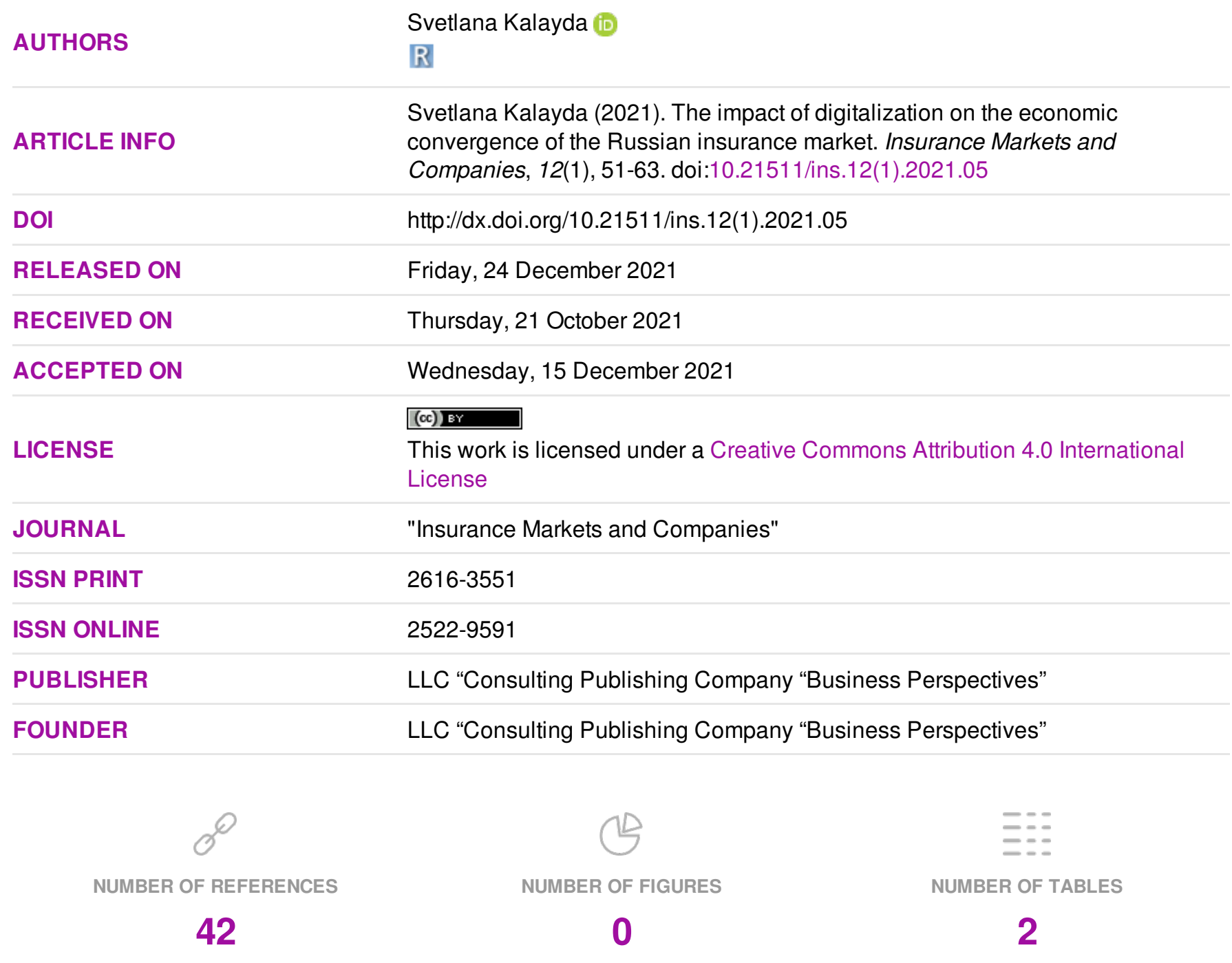

(c) The author(s) 2021. This publication is an open access article. 


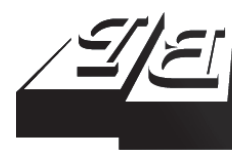

\section{BUSINESS PERSPECTIVES}

LLC "CPC "Business Perspectives" Hryhorii Skovoroda lane, 10, Sumy, 40022, Ukraine www.businessperspectives.org
Received on: $21^{\text {st }}$ of October, 2021 Accepted on: $15^{\text {th }}$ of December, 2021 Published on: 24 ${ }^{\text {th }}$ of December, 2021

(C) Svetlana Kalayda, 2021

Svetlana Kalayda, Ph.D. in Economics, Associate Professor, Department of Risk Management and Insurance, The Faculty of Economics, Saint Petersburg State University, Russian Federation.
This is an Open Access article, distributed under the terms of the Creative Commons Attribution 4.0 International license, which permits unrestricted re-use, distribution, and reproduction in any medium, provided the original work is properly cited.

Conflict of interest statement: Author(s) reported no conflict of interest
Svetlana Kalayda (Russian Federation)

\section{THE IMPACT OF DIGITALIZATION ON THE ECONOMIC CONVERGENCE OF THE RUSSIAN INSURANCE MARKET}

\begin{abstract}
The most important trends in the modern economy are convergence - the process of convergence of activities of various economic entities and digitalization. Their interaction creates new opportunities for increasing the competitiveness and efficiency of insurance companies. The purpose of the paper is to identify economic convergence processes taking place on the Russian insurance market, which, when using different digitalization products, lead to new business models of partnership. The results of the conducted empirical analysis confirm the existence of economic convergence processes at all levels (intra-segment, intersegment and inter-sectoral) on the Russian insurance market. The proof of this is the significant reduction in the number of insurers in 2021 to 158 , compared to 600 insurers in 2011. Over the past three years, the share of sales of insurance products with the participation of banks acting as intermediaries in the sales of insurance services has increased by 1.5 times. Also, along with insurance companies, health care companies have increasingly become involved in such operations. Digitalization products (information technologies (IT); IT and IT platforms; IT, IT platforms and networks) have a huge impact on the forms of organizing joint business with the participation of insurance companies. Some insurance companies do not provide opportunities to issue an insurance policy online or pay an insurance premium, i.e. they use sites for only minor customer interactions. Most often, Russian insurance companies use mobile applications. The impact of various digitalization products at different levels of economic convergence of insurers initiates multivariate business models of joint business.
\end{abstract}

\section{Keywords}

economic convergence, joint business, partnership, digitalization, digitalization products, business model, ecosystem

\section{JEL Classification $\quad$ G22, O16, O31}

\section{INTRODUCTION}

Insurance, as an institution of financial and social protection of society members, a country's economy and as the most important source of investment resources, is a significant segment not only of the financial market, but of the entire economy. One of the most important mechanisms to increase the competitiveness of any business entity at the present stage is economic convergence - the process of bringing the activities of different companies and enterprises closer together. Economic convergence processes cover the entire economy, but they are especially pronounced in the financial market, taking into account the participation of insurance companies. The modern opportunities provided by digitalization, as well as life in the conditions of the COVID-19 pandemic, require the activation and strengthening of convergence at different levels of the economy. In this context, it is worth quoting experts from the Reinsurance Group of America (RGA, 2021): "As we continue to speculate how the "new normal" will unfold, insurance market dynamics will continue to shift, while technology increases the pace and breadth of change. In order to meet new con- 
sumer needs with speed, agility, and innovation, a life insurer's focus must be on combining proven approaches with new ways of doing business via collaboration and co-development. Today's successful life insurers are collaborating at scale with ecosystem partners such as insurtechs and technology providers to acquire business-critical capabilities that maximize new business operating models." An empirical analysis of new business models of joint economic activities that appear on the insurance market under the influence of digitalization becomes a prerequisite for the future assessment of their effectiveness and selection of the best option.

\section{LITERATURE REVIEW}

The use of economic convergence as an instrument to increase the competitiveness of economic entities is increasingly confirmed. At the same time, digitalization as the most important trend in modern society, has a significant impact on the processes of economic convergence. Numerous works have been devoted to the study of its impact on national economies. Considering the modernization of the economy under the influence of digitalization, Sembekov et al. (2021) note the change in its structure and the emergence of new digital sectors as the basis of the new information economy. Examining digitalization processes, Golovenchik (2019) notes a change in business models under the influence of global digitalization, a change in the business processes of enterprises and organizations with the introduction of new technologies. Khalin and Chernova (2018), Chernova et al. (2019) pay special attention to the manifestation of digitalization at different levels of the economy, including the risks of digitalization for the Russian economy.

At the same time, most authors agree that digitalization has a significant impact on the development of the financial sector of the economy (Dankiewicz et al., 2020; Mustafina et al., 2020; Volosovych et al., 2021). Thus, Zhang and Chen (2019) define the highest level of the development of the digital economy in the financial sector in China. Maramygin et al. (2019) note the gradual blurring of the boundaries of the financial industry and the cooperation of financial structures with representatives of other sectors of the economy as a result of the financial market's digital transformation. According to Gawer (2021), Boyer et al. (2021), Birch and Cochrane (2021), this creates new forms of business organization. Of particular interest are business models that, within a certain level of economic convergence under the influence of digitalization, ensure its greatest growth and the maximum increase in the initiator's competitiveness (Kalayda, 2021; Abdelmoneim \& Fekry, 2021).

Convergence processes on financial markets, especially with the participation of insurance companies, were reflected by Kuznetsova et al. (2016), Dowrick and Bradford (2003). Pisarenko and Chernova (2015) believe that economic actors are forced to look for new forms of doing joint business at different levels of convergence due to increased competition. An increase in business efficiency with economic convergence is possible if certain prerequisites for its creation are realized in a joint business, the positive influence of external factors is taken into account, and the business model itself contributes to an increase in the competitiveness of the initiator of convergence (Khalin et al., 2021). The insurance sector is a significant segment of the financial market, therefore, by using its example many authors demonstrate the change in the market and its structure under the influence of the digital economy (Kaigorodova et al., 2020a). Studying the practice of M\&A transactions on the insurance market of the Russian Federation, Tarasova (2014) explores the processes of intra-segment economic convergence, but does not name them directly. Kalayda and Malova (2018) confirm these processes - they draw conclusions about the reduction of insurers due to the consolidation of the insurance business. Among the additional factors that have a positive effect on the processes of economic convergence of the insurance market in the Russian Federation, Kalayda (2017) highlights the adopted legislative standards of the regulator, which become uniform for all participants in the financial market of the Russian Federation.

When assessing the impact of digitalization on the economy, Khalin and Chernova (2020) and Chernova et al. (2019) distinguish three main 
stages of its development, reflecting the gradual complication of digitalization instruments. In this regard, they determine the result (product) of the first stage of digitalization - information technologies (IT), the product of the second stage - IT and IT platforms, and the product of the third stage - IT, IT platforms and networks that unite them. Kalayda and Faizova (2020) consider the features of the use of modern digital innovations by insurance companies in their internal business processes. Examining the digital transformation of the insurance markets in the US and EU countries, Cappiello (2018) notes the role of innovative technologies in increasing the competitiveness of insurance companies.

Levchishina et al. (2020) focus on the role of insurance in the development of innovation by covering innovative and digital risks, which can be considered as an option for mutually beneficial cooperation between insurance and innovative companies. Baranauskas and Raišiene (2021) highlight new business organization models (digital platforms) in the Baltic insurance market. New forms of cooperation between insurers and other companies are explored by Klapkiv et al. (2020), Zhilkin and Mantsurov (2016), and Holiavko (2021). Akhvlediany (2021) confirms the increase in the level of digital interaction in the Russian insurance market, which leads to the transformation of the insurance industry in the conditions of sustainable development. Faizova et al. (2020), Doszhan et al. (2020), Kaigorodova et al. (2020b), and Kaigorodova et al. (2021) note the transformation of business processes and the increase in the possibilities of insurance companies in the implementation of digital innovation, but at the same time, they identify new risks. Modern scientific works also explore the issues of modernizing the regulation of national insurance markets caused by the impact of digitalization (Kotlobovsky \& Zhang, 2021).

Ponomarenko et al. (2021) highlighted that “... digitalization has evolved from the automation process, where workflows are algorithmized and transferred to digital format. The following features characterize this process: rethinking of the external communication customer-oriented model with partners and customers; the emergence of a sharing business model of the company; chang- ing the working model, based on the use of artificial intelligence and decision-making in terms of incomplete and asymmetric information; internal communications transformation and relations outsourcing and freelancing."

Alekseieva et al. (2021) argue that "...the pandemic caused the intensification of digitalization processes in the economy and all the events, in particular, specialized network platforms such as Enterprise Europe Network obtain new virtual forms."

There is a specificity of the very processes of economic convergence occurring at the intra-segment, intersegment and inter-sectoral levels. This affects the content of joint activities organized within a certain level of economic convergence, in which the insurer becomes a participant (Tsvetkova et al., 2021). Digitalization has also an impact on the joint business created within the framework of economic convergence - through its digitalization products. The variety of these products has a different effect on the content of the created joint business, in which the Russian insurer becomes a participant.

The processes of economic convergence, based on the convergence of activities conducted by various economic entities, are a mechanism for increasing the competitiveness of the initiator of the joint business creation. The desire of an economic entity to increase its competitiveness by bringing its activities closer to the activities of other economic entities determines the creation of various forms of organizing a joint business, aimed primarily at increasing the efficiency of its own activities. This trend is also observed on the insurance market.

The purpose of the paper is to identify the processes of economic convergence taking place on the Russian insurance market, which, when using different digitalization products, lead to the formation of new business models of partnership.

\section{GENERALIZATION OF MAIN STATEMENTS}

The convergence of activities of economic entities, aimed at increasing the competitiveness of its initiator, is manifested within the framework of: 
- intra-segment economic convergence, when the initiator plans to increase his own competitiveness by converging with the activities of an economic entity (or entities) of the same segment of the economy in which he operates;

- intersegment economic convergence, the goal of which is to increase the initiator's own competitiveness due to convergence with the activities of an economic entity (or entities) operating in a segment of the economy other than that of the initiator;

- inter-sectoral economic convergence, which implies an increase in the competitiveness of the initiator due to convergence with the activities of an economic entity (or entities) working in any other than that of the initiator's sector of the economy.

At first, the processes of economic convergence on the Russian insurance market manifested themselves at the intra-segment level - the convergence took place within the insurance segment and only the subjects of the insurance market were involved in the joint business. As the main prerequisite for intra-segment convergence on the Russian insurance market, one can consider the possibility of creating a single client base of policyholders, the use of which in a joint business provides significant competitive advantages, primarily due to an increase in sales volumes. An example of an additional factor contributing to the convergence of economic entities' activities on the insurance market (in addition to increased competition) is the regulatory influence that insurance companies are exposed to as potential participants in convergence: this is an increase in the requirements for the minimum authorized capital of insurers, a change in the principles of accounting and financial reporting (introduction of IFRS, transition of insurers to accounting plans, etc.).

A peculiar feature of business models in intra-segment convergence is the use of two main forms of its implementation - voluntary and aggressive, which can affect the level of efficiency of joint business:

- Voluntary form - cooperation between an insurance company and a bank on the ba- sis of an agency agreement. The bank, being an agent of an insurance company, sells insurance policies and receives income in the form of commission. Within the framework of intersegment convergence, this form of a business model is characterized by the bank's ability to provide additional services (in addition to the main banking services), as well as through the implementation of the goals of the convergence participants - both the insurance company (initiator) and the bank realize their goals by receiving funds in the form of insurance premiums and agency commission, respectively.

- Aggressive form of economic convergence is the initiation by the bank of the convergence process with the insurance company.

An increase in competition on the insurance market of the Russian Federation, which took place between individual insurance companies and insurance groups formed within the framework of intra-segment economic convergence, necessitated the search for new means and ways of their effective development by the subjects of the Russian insurance market. As a mechanism to increase their competitiveness, many of them began to choose options for cooperation within the framework of economic convergence with entities from adjacent segments of the financial market, primarily with banks and non-state pension funds. An additional prerequisite for this was the similarity of products provided by the financial market's entities - primarily banking, insurance and investment, allowing the client to receive investment income.

The active participation of insurance companies in the processes of the next level of convergence - inter-sectoral - is due to the significant positive influence of the digitalization factor. Thanks to this influence, the subjects of the Russian insurance market, in order to increase the efficiency of their activities and in search of options for profitable cooperation, began to go beyond the financial market - to other sectors of the economy. A number of companies carry out joint business activities with representatives of other segments and sectors of the economy implementing a number of business models for inter-sectoral convergence on the Russian insurance market. 
It should be noted that digitalization is provided by three levels of products:

1) the product of the first stage of digitalization information technologies (IT): these are technologies for maintaining a database and supporting individual business processes of the insurer (creating a single client base, as well as a database for maintaining and servicing insurance contracts);

2) the product of digitalization of the second stage - IT and the IT platform - is the development and use by the insurance company of its own website in the information and telecommunications network "Internet";

3) the digitalization product of the third stage - (IT, IT platforms and networks) - the most complex digitalization product, an example of which can be the websites of insurance companies, but only those that, interacting with other IT platforms through networks, provide additional opportunities to their customers.

The basic examples of economic convergence processes occurring with the use of different digitalization products with the participation of insurers are presented in Table A1 (Appendix A).

The greatest positive effect from digitalization products can be observed provided that not only individual information technologies are used, but also platforms, as well as networks that connect them. The transition to the use of more complex digitalization products is explained by their technical characteristics and the possibilities of a stimulating influence on the business itself.

\section{DISCUSSION}

The processes of intra-segment convergence on the insurance market of the Russian Federation manifested themselves in the consolidation of the insurance business. Realizing the relevant factors and prerequisites, individual insurance companies carried out the convergence of their activities through mergers and acquisitions. A good example was the acquisition in the early 2000 s by the Alliance insurance company of two insurance companies, Rosno and Progress-Garant. Another manifestation of intra-segment convergence was the formation of insurance groups, for example, the emergence in the mid-2000s of the insurance group Soglasie, represented by the insurance company Soglasie, which carries out insurance services other than life insurance, and the company Soglasie-Vita, which offers life insurance. The implementation of the joint business within the framework of intra-segment convergence in the form of insurance groups allows insurers to occupy leading positions on the insurance market of the Russian Federation. The analysis of indicators of total insurance premiums (for life insurance and other types of insurance) confirms that the leaders of the Russian insurance market at the end of 2020 are the Sogaz group of companies (indicators are included only for the Sogaz and Sogaz-life companies), Alfa, Sberbank, Ingosstrakh, ResoGarantia, Rossgostrakh. At the end of 2020, in total these six insurance groups collected more than $65 \%$ of revenues of all Russian insurers.

The processes of intra-segment convergence continue on the Russian insurance market even now. Thus, in the spring of 2021 insurance companies Helios and Verna announced the merger of their activities, in which the insurance portfolio of Verna is transferred to Helios. As a result of the merger of these two insurers, a new universal player under the Helios brand will appear on the insurance market. Thanks to the voluntary form of implementation of such integration, which makes it possible, among other things, to unite in the future joint business all the best that the convergence participants had before the convergence: resources, products, technologies, etc., it will have an opportunity to become more financially stable and solvent. The participation in the process of intra-segment convergence will allow the owners of these two subjects of the insurance market to bring the joint business to a qualitatively new high level of development and increase its competitiveness.

The ongoing processes of intra-segment economic convergence maintain a tendency towards a reduction in the number of insurance subjects due to the consolidation of the insurance business and exit from the market in various ways (entirely or due to participation in the processes of economic convergence) of small and medium-sized insur- 
ance companies. This is confirmed by statistical data. If as of January 1, 2011, according to the Bank of Russia, more than 600 insurance organizations were operating on the insurance market, then by July 1, 2021, only 158 insurers were registered.

The insurance market of the Russian Federation was and is still characterized by the processes of intra-segment convergence. This is demonstrated by the amalgamation of various insurance companies, which is accompanied by the consolidation of the remaining players on the Russian insurance market.

Insurance companies increasingly choose cooperation with entities from adjacent segments of the financial market (with banks and non-state pension funds) as an instrument to increase their competitiveness. Investment life insurance products are an example of this. Thus, the insurance company Ingosstrakh with the participation of the management company Ingosstrakh-Investments offers its clients the program of investment life insurance Vector, which provides not only insurance coverage (insurance payment) in the event of death as a result of an accident or road accident, but also the receipt of investment income by beneficiaries in the amount of up to $200 \%$ and up to $300 \%$ of contribution, respectively. Another example of cooperation between financial market entities is the Alfa-Reserve program of Alfa Life Insurance Company, which provides the service with the help of partners - Rostfinance and Alfa Bank banks.

The strengthening of the processes of intersegment economic convergence on the Russian insurance market is facilitated by the factor of similarity of the legislative framework that regulates the activities of participants of this level of convergence the subjects of the financial market. It manifested itself in creating a single regulator for the financial market represented in the Central Bank of the Russian Federation and in the trend common for all subjects of the financial market of the Russian Federation of creating uniform rules to regulate financial aspects of their activities. An example of this is the introduction in 2017 of a new accounting plan for non-bank financial institutions, which was based on the accounting plan for credit institutions. This means the convergence of uni- form accounting rules for the entire financial market. An additional confirmation of the increasing importance of the factor of similarity of the legislative framework is a very similar procedure for investing insurance reserves formed by insurance organizations and non-state pension funds.

New forms of organizing joint business (business models) that appear within the framework of intersegment economic convergence are determined by the values of parameters of their activities (voluntary and aggressive). It should be noted that in the Russian Federation, the share of sales of insurance products with the participation of banks acting as intermediaries in the sales of insurance services is constantly increasing. Thus, compared to 2017, in 2020 the share of sales of insurance products with the participation of banks increased by 1.5 times.

Another option for the business model of intersegment convergence is the bank's initiation of the process of convergence with the insurance company: the deal on the acquisition by Sovkombank at the end of 2019 of the insurance company Liberty Insurance. As a result of this acquisition the insurer became known as Sovkombank Insurance, and the volume of insurance premiums of this company increased significantly, largely due to convergence, which is also confirmed by the growth in sales of insurance contracts with the participation of banks. There is also a significant increase in the insurer's own funds: from 600 million rubles as of September 6, 2018 up to 1,600 million rubles as of June 30, 2021.

Another example of a business model of intersegment convergence on the Russian insurance market is the participation of the Ingosstrakh insurance company in the authorized capital of the Soyuz bank (share of participation -95.86\%) or the creation by the Rosgosstrakh insurance company of the bank with the same name - Rosgosstrakhbank. Unlike the previous example, here the initiator is the subject of the insurance market.

All processes of intra-segment convergence on the Russian insurance market at the initial stage of a joint business creation felt the impact of digitalization through its simplest product of the first stage of digitalization - information technologies (IT). 
As regards digitalization products of the second stage, the use of IT platforms on the Russian insurance market is observed not only in the activities of companies participating in the processes of economic convergence, but also in those that conduct business independently. The recognition of the need to use more complex digitalization products such as IT and IT platforms in the insurance business is the obligatory use of them by insurers, which is enshrined in the Law "On the Organization of Insurance Business in the Russian Federation". Currently, through their websites, insurers provide clients with information about their companies and their financial indicators, inform their clients about the main insurance services, provide opportunities for quotations on some insurance products, etc. (Capital-Policy insurance company, etc.). Given the definition of the platform proposed by the Organization for Economic Cooperation and Development - "it is a digital service designed to improve interaction over the Internet between two or more interdependent groups of users", the website can really be considered as a platform through which certain interactions with customers are carried out (OECD, 2019). However, this stage in the development of digitalization does not fully reflect all the positive advantages and opportunities of the current level of digitalization. Some insurance companies do not provide an opportunity to issue an insurance policy online or pay an insurance premium, i.e. they also use their sites only for minor interaction with their insured clients - in fact, only for informing clients - Solidarity insurance company, Geopolis insurance company, etc.

IT and IT platforms are a more complex digitalization product that is actively used by insurance companies operating independently or within the framework of economic convergence. However, it should be noted that, unfortunately, not every insurance company uses all the possibilities provided by this product.

The application of the second stage digitalization product is observed on the Russian insurance market not only within the framework of intra-segment, but also inter-segment economic convergence. This can be confirmed by the participation of the insurance company as a partner in the intersegment convergence initiated by the bank. Through its website (as an IT platform), the client can receive information about insurance products. For example, on the VTB bank's website in the "Other Services" section one can study offers on insurance products and, if necessary, draw up an contract through the VTB online bank.

The positive influence of the digitalization factor led to the participation of insurance companies in inter-sectoral convergence. First of all, health care companies began to participate in the processes of inter-sectoral convergence along with insurance companies. An example of this is the initiation of convergence processes with medical companies by insurance organizations in the form of creating their own medical centers, participating in the authorized capital of medical companies, etc. The analysis shows that insurance companies that carry out this kind of joint business with medical companies within the framework of economic convergence can be of different sizes - both big companies and smaller ones: Gaide (Gaide multidisciplinary medical centers), Ingosstrakh (its own network of multidisciplinary clinics Be Healthy), CapitalPolicy (Medical Center Capital-Policy), insurance group Sogaz (Group of clinics Sogaz Medicine), etc. Another version of the business model of inter-sectoral convergence with the participation of the insurance market entity is the provision of various services under the subscription "Ogon" by the insurance group Sogaz and its partners. By purchasing such subscription, the policyholder can receive advantageous offers and discounts not only in insurance and finance, but also on mobile communications or health and electronics products, as well as free access to watching movies, etc. Among the partners of the insurer are Gazprombank, Gazpromneft gas stations, Lenta stores, Gazprombank Car Leasing, pharmacy chain Acha, Rive-Gauche cosmetics and perfumery stores, etc. These examples confirm the existence of cross-sectoral economic convergence processes taking place on the Russian insurance market.

The most complex digitalization product (IT, IT platforms and networks) can provide additional opportunities to their customers (Table A2, Appendix A).

The possibilities of economic convergence of different levels with the participation of insurance market entities are enhanced when, at different stages of business processes, they use the follow- 
ing modern technologies and devices based on the latest achievements of digitalization - the product of digitalization of the third stage:

- Insurance chat bots - automatic systems created to communicate with policyholders via SMS, website or messenger on issues of registration and sales of insurance policies, advice on claims settlement, etc. For example, the developed service “@osago_robot” is intended for use at the level of intra-segment convergence in the implementation of MTPL policies by several insurance companies. The medical chatbot used by the insurance company Sberbank Insurance can recognize more than 350 symptoms of the disease and determine the doctor to whom the client can turn. Such technologies can be used at all levels of convergence, depending on the participants and provided services (for example, in the event of an insured event for comprehensive insurance - assistance in filling out an application for an insured event, tow truck services, medical institution services, etc.).

- Telematics - equipment that allows an insurer to track the insurance object in real time in order to control and assess the level of risk, etc. For example, integrated navigation and information services give certain advantages to insurance companies in the sales and maintenance of motor hull insurance policies, and their partners - car dealers - on the acquisition of a new client and the possibility of installing (activating) such equipment.
- Mobile applications. Russian insurance companies actively use such technologies in various business processes and carry out certain types of joint activities within the framework of different levels of convergence. The insurance company VSK, using its mobile application, provides an opportunity to get advice from doctors within the framework of a personal insurance contract, and for comprehensive car insurance - the ability to call an emergency commissioner and a tow truck. The mobile application of the Sogaz insurance company allows a client not only to issue and pay for an insurance policy, but also to receive information about his health status from the "Medical Card" section: doctors' opinions, tests, vaccinations, allergies, medications, etc. At the same time, it is possible to enter through the "State Services" website.

The conducted analysis confirmed the presence of intersegment convergence processes on the insurance market of the Russian Federation. They manifest themselves in the implementation of different variants of business models of this level of convergence. These include cooperation between insurance companies and banks within the framework of agency agreements for the sales of insurance services, active participation of insurers in the authorized capital of credit institutions, as well as their passive participation in convergence models initiated by banking institutions.

\section{CONCLUSION}

The Russian insurance market is characterized by the manifestation of economic convergence processes at different levels, which, when using various digitalization products, lead to the formation of new business models of partnership. Intra-segment convergence manifests itself in the consolidation of participants on the Russian insurance market. Intersegment convergence is characterized by the implementation by financial market entities of various options for organizing joint business, such as mutual participation in capital, cooperation based on agency agreements, etc. The active manifestation of the processes of inter-sectoral economic convergence is confirmed by the joint activities of Russian insurance companies with representatives from the healthcare and automotive industries. As the analysis shows, the purpose of creating a joint business is most often the mutual interests of the parties.

Given the rapid pace of digitalization, within the framework of intersegment and inter-sectoral convergence, one can observe the use of not only individual information technologies, but also platforms and networks that unite them. The transition to the use of more complex digitalization products is explained 
by their technical characteristics and the possibility of a positive impact on the business itself. The latter confirms the growing influence of digitalization on the processes of economic convergence taking place on the Russian insurance market. The analysis showed that the most promising in the insurance market of the Russian Federation are business models of inter-sectoral convergence using the most complex digitalization product, namely IT, IT platforms and networks that unite them. In general, digitalization contributes to the acceleration of the processes of economic convergence on the Russian insurance market, increases the efficiency of insurance coverage and corresponds to the development of insurance as the most important institution of financial and social security.

\section{AUTHOR CONTRIBUTIONS}

Conceptualization: Svetlana Kalayda.

Formal analysis: Svetlana Kalayda.

Funding acquisition: Svetlana Kalayda.

Investigation: Svetlana Kalayda.

Methodology: Svetlana Kalayda.

Project administration: Svetlana Kalayda.

Visualization: Svetlana Kalayda.

Writing - original draft: Svetlana Kalayda.

Writing - review \& editing: Svetlana Kalayda.

\section{REFERENCES}

1. Abdelmoneim, Z., \& Fekry, M. A. (2021). Using managerial and market tools to measure the impact of acquisition operations on firm performance. Investment Management and Financial Innovations, 18(1), 315-334. http://dx.doi.org/10.21511/ imfi.18(1).2021.26

2. Akhvlediany, Y. (2021). Tsifrovoye strakhovanie kak faktor ustoychivogo razvitiya ekonomiki [Digital Insurance as a Factor of Sustainable Economic Development]. Strakhovoe delo - Insurance Business, 11(344), 43-49. (In Russian).

3. Alekseieva, K., Novikova, I., Bediukh, O., Kostyuk, O., \& Stepanova, A. (2021). Technological orders' change caused by the pandemics: Digitalization in the internationalization of technology transfer. Problems and Perspectives in Management, 19(3), 261-275. http://dx.doi.org/10.21511/ ppm.19(3).2021.22

4. Bank of Russia. (2021). Statistics Insurance. Retrieved from https:// cbr.ru/statistics/insurance/

5. Baranauskas, G., \& Raišiene, A. G. (2021). Reflections on the
Customer Decision-Making Process in the Digital Insurance Platforms: An Empirical Study of the Baltic Market. Applied Sciences, 11, 8524. https://doi.org/10.3390/ app11188524

6. Birch, K., \& Cochrane, D. T. (2021). Big Tech: Four Emerging Forms of Digital Rentiership. Science as Culture. http://dx.doi.org/1 0.1080/09505431.2021.1932794

7. Boyer, J., Ozor, J., \& Rondé, P. (2021). Local innovation ecosystem: structure and impact on adaptive capacity of firms. Industry and Innovation, 28(5), 620-650. http://dx.doi.org/10.1080/1366271 6.2021 .1891407

8. Cappiello, A. (2018). Technology and the Insurance Industry: Reconfiguring the Competitive Landscape. Springer, Cham. http://doi. org/10.1007/978-3-319-74712-5

9. Chernova, G., Khalin, V., \& Yurkov, A. (2019). Digitalization and its impact on the development of Russia. Journal of Applied Informatics, 14(5), 41-52. Retrieved from http://www.appliedinformatics.ru/general/upload/articles_preview/p41[9].pdf
10. Dankiewicz, R., Tworzydło, D., \& Ostrowska-Dankiewicz, A. (2020). Distribution of services within the call center and Covid 19 - a case study. WSEAS Transactions on Business and Economics, 17, 921-932. http://dx.doi. org/10.37394/23207.2020.17.90

11. Doszhan, R., Nurmaganbetova, A., Pukala, R., Yessenova, G., Omar, S., \& Sabidullina, A. (2020). New challenges in the financial management under the influence of financial technology. E3S Web of Conferences, 159, 04015. https://doi.org/10.1051/e3sconf/202015904015

12. Dowrick, St., \& Bradford, J. D. (2003). Globalization and Convergence. In M. D. Bordo, A. M. Taylor \& J. G. Williamson (Eds.), Globalization in Historical Perspective. USA: University of Chicago Press. Retrieved from https://www. nber.org/system/files/chapters/ c9589/c9589.pdf

13. Faizova, A., Kalayda, S., Malova, I., \& Solopenko, E. (2020). The Impact of Digitalization Risks on the Business Processes of an Insurance Company. III International Scientific and Practical 
Conference "Digital Economy and Finances" (ISPC-DEF 2020). Atlantis Press. http://dx.doi.org/10.2991/ aebmr.k.200423.001

14. Gawer, A. (2021). Digital platforms and ecosystems: remarks on the dominant organizational forms of the digital age. Innovation: Organization \& Management. https://doi.org/10.1080/14479338. 2021.1965888

15. Golovenchik, G. G. (2019). Tsifrovizatsiya belorusskoy ekonomiki $v$ sovremennykh usloviyakh globalizatsii [Digitalization of the Belarusian economy in modern conditions of globalization]. Minsk: Publishing center BSU. (In Russian). Retrieved from https://elib. bsu.by/handle/123456789/225877

16. Holiavko, A. (2021). Polis budushhego: kak tehnologii meniayut strakhovoi biznes [Policy of the future: how technology changes the insurance business]. Forbes. (In Russian). Retrieved from https://www.forbes. ru/partnerskie-materialy/433077polis-budushchego-kak-tehnologii-menyayut-strahovoy-biznes

17. Kaigorodova, G., Mustafina, A., Pyrkova, G., Grzebyk, M., \& Belinskaja, L. (2021). Digitalization of the insurance business: Systematization of net effects through the example of Russia. Insurance Markets and Companies, 12(1), 32-42. http://dx.doi.org/10.21511/ ins.12(1).2021.03

18. Kaigorodova, G., Mustafina, A., Pyrkova, G., Mamchur, R., Zelenitsa, I., \& Kul, T. (2020a). Growth factors of insurance interests of russian citizens. Proceedings 36 th International Business Information Management Association Conference, IBIMA. Granada, Spain. Retrieved from https://ibima.org/ accepted-paper/growth-factorsof-insurance-interests-of-russiancitizens/

19. Kaigorodova, G., Mustafina, A., Pyrkova, G., Vyukov, M. \& Davletshina, L. (2020b). Cyber risks for insurance company. In Digital Transformation of the Economy: Challenges, Trends and New Opportunities (pp. 669-677) Springer, Cham. Retrieved from https://link.springer.com/chapte r/10.1007/978-3-030-11367-4_64
20. Kalayda, S. A. (2017). Regulirovanie finansovykh aspektov deyatelnosti strakhovshchika na sovremennom etape [Regulation of financial aspects of the insurer's activities at the present stage]. Strakhovoye delo - Insurance Business, 12(297), 17-25. (In Russian). Retrieved from https://elibrary.ru/ item.asp?id=32253923

21. Kalayda, S. A. (2021). Model formirovaniya ekonomicheskoy ekosistemy v ramkakh ekonomicheskoy konvergentsii pod vliyaniyem tsifrovizatsii [Model of creating an economic ecosystem in the framework of economic convergence under the influence of digitalization]. Prikladnaya Informatika - Journal of Applied Informatics, 6(96), 28-42. (In Russian). Retrieved from http:// www.appliedinformatics.ru/r/ articles/article/index.php?article_ id_4=2781

22. Kalayda, S. A., \& Faizova, A. A. (2020) Primeneniye tsifrovykh tekhnologiy na strakhovom rynke Rossii [Application of digital technologies in the Russian insurance market]. Materialy mezhdunarodnykh nauchnykh konferentsiy: «Ustoychivoye razvitiye: obshhestvo i ekonomika», «Sokolovskiye chteniya. Buhgalterskiy uchet: vzgliad iz proshlogo $v$ budushchee»-Materials of international scientific conferences: "Sustainable development: society and economics," "Sokolovsky readings. Accounting: looking from past to future", 423-428. St. Petersburg State University, St. Petersburg. (In Russian). Retrieved from http:// hdl.handle.net/11701/22820

23. Kalayda, S. A., \& Malova, I. V. (2019). Aktualnyye problemy razvitiya strakhovogo rynka $\mathrm{v}$ regionakh RF [Current problems of the insurance market in the Russian regions]. Current management problems: Management as the most important factor in economic growth and raising the standard of living in the regions: materials of the international scientific and practical conference, 108-110. St. Petersburg State University, Scythia Print.(In Russian).
24. Khalin V. G., \& Chernova G. V. (2018) Tsifrovizatsiya i yee vliyaniye na rossiyskuyu ekonomiku i obshchestvo: preimushchestva, vyzovy, ugrozy i riski [Digitalization and Its Impact on the Russian Economy and Society: Advantages, Challenges, Threats and Risks]. Administrative Consulting, 10, 46-63. (In Russian). https://doi. org/10.22394/1726-1139-201810-46-63

25. Khalin, V. G., \& Chernova, G. (2020). Tsifrovizatsiya i ee vliyanie na sovremennuyu ekonomicheskuyu konvergentsiyu metodologicheskiy aspect [Digitalization and Its Impact on Modern Economic Convergence - Methodological Aspect]. Administrative Consulting, 8, 78-87. (In Russian). https://doi.org/10.22394/17261139-2020-8-78-87

26. Khalin, V. G., Chernova, G. V., \& Kalayda, S. A. (2021). Ekonomicheskiye ekosystemy i ikh klassifikatsiya [Economic Ecosystems and Their Classification]. Administrative Consulting, 2, 38-54. (In Russian). Retrieved from https://cyberleninka.ru/article/n/ ekonomicheskie-ekosistemy-i-ihklassifikatsiya/viewer

27. Klapkiv, Y., Vovk, V., \& Klapkiv, L. (2020). Comparative analysis of the health care institutions' competitiveness level. Montenegrin Journal of Economics, 16(3), 69-82. https://doi.org/10.14254/18005845/2020.16-3.6

28. Kotlobovsky, I. B., \& Zhang, S. (2021). Opyt regulirovaniya strakhovoy otrasli KNR v usloviyakh tsifrovizatsii [Experience of China in Regulation Insurance Industry in Context of Digitalization]. Strakhovoe Delo - Insurance Business, 10(343), 53-60. (In Russian).

29. Kuznetsova, N. P., Pisarenko, Zh. V., \& Chernova, G. V. (2016). Financial market institutions competitiveness and financial convergence. International Conference "New Challenges of Economic and Business Development - 2016. Society, Innovations and Collaborative Economy", 443-458. University of Latvia. Retrieved from https:// www.bvef.lu.lv/fileadmin/user upload/lu_portal/projekti/bvef/ 
konferences/konference_2016/ Proceedings.pdf

30. Levchishina, A., Solopenko, E., \& Kalayda, S. (2020). Features of Innovation Insurance in Russia. International Scientific and Practical Conference: Digital Finance 2020 (DF2020), 143-147. Filodiritto Publisher.

31. Maramygin, M .S., Chernova, G. V., \& Reshetnikova, L. G. (2019). Digital transformation of the financial services market in Russia: Trends and specificity. Upravlenets - The Manager, 10(3), 70-82. (In Russian). https://doi. org/10.29141/2218-5003-201910-3-7

32. Mustafina, A., Kaigorodova, G., Alyakina, P., Velichko, N., \& Zainullina, M. (2020). Digital technology in insurance. In Digital Transformation of the Economy: Challenges, Trends and New Opportunities (pp. 678-685). Springer, Cham. Retrieved from https://link.springer.com/chapte r/10.1007/978-3-030-11367-4_65

33. OECD. (2019). An Introduction to Online Platforms and Their Role in the Digital Transformation. OECD Publishing: Paris. https://doi. org/10.1787/53e5f593-en

34. Pisarenko, Zh. V., \& Chernova, G. V. (2015). Financial convergence as a tool to increase the competitive ability of financial market participants. Finance and Credit, 46(670), 10-23. (In Russian). Retrieved from https://cyberleninka. $\mathrm{ru} /$ article/n/finansovaya-konvergentsiya-kak-mehanizm-povysheniya-konkurentosposobnostisubektov-finansovogo-rynka/ viewer

35. Ponomarenko, V., Rayevnyeva, O., Yermachenko, V., Aksonova, I., \& Brovko, O. (2021). Digitalization as a development factor of innovative-active university. Problems and Perspectives in Management, 19(4), 213-231. https://doi. org/10.21511/ppm.19(4).2021.18

36. RGA. (2021). COVID-19 Pandemic Accelerates Convergence in Insurance Distribution. Retrieved from https://www.rgare.com/ knowledge-center/media/covid-19/covid-19-pandemic-accelerates-convergence-in-insurancedistribution

37. Sembekov, A., Tazhbayev, N., Ulakov, N., Tatiyeva, G., \& Budeshov, Ye. (2021). Digital modernization of Kazakhstan's economy in the context of global trends. Economic Annals-XXI, 187(1-2), 51-62.

38. Tarasova, Y. A. (2014). Keys-analiz rossiyskikh sdelok po sliyaniyu na strakhovom rynke [Case analysis of Russian merger transactions in the insurance market]. (In Russian). Retrieved from https://spb.hse.ru/ press/114478604.html

39. Tsvetkova, L., Bugaev, Y., Belousova, T., \& Zhukova, O. (2021). Factors affecting the performance of insurance companies in Russian federation. Montenegrin Journal of Economics, 17(1), 209-218. https://doi.org/10.14254/18005845/2021.17-1.16

40. Volosovych, S., Zelenitsa, I., Kondratenko, D., Szymla, W., \& Mamchur, R. (2021). Transformation of insurance technologies in the context of a pandemic. Insurance Markets and Companies, 12(1), 1-13. https://doi.org/10.21511/ ins.12(1).2021.01

41. Zhang, L., \& Chen, S. (2019). China's Digital Economy: Opportunities and Risks. International Organizations Research Journal, 14(2), 275-303. (In Russian). https://doi.org/10.17323/19967845-2019-02-11

42. Zhilkin, O., \& Mantsurov, K. (2016). Integration of the Telemathic Tools in the Activity of Insurance Companies. The "Smart Insurance". Vestnik Universiteta University Bulletin, 7-8, 202-207. (In Russian). Retrieved from https://vestnik.guu.ru/jour/article/ view/333/1348 


\section{APPENDIX A}

Table A1. Possible options for cooperation between participants of economic convergence, based on the use of a specific digitalization product

\begin{tabular}{|c|c|c|c|}
\hline \multirow{2}{*}{$\begin{array}{l}\text { Digitalization } \\
\text { product }\end{array}$} & \multicolumn{3}{|c|}{ Convergence level } \\
\hline & Intrasegment & Intersegment & Intersectoral \\
\hline IT & $\begin{array}{l}\text { Insurance companies - members } \\
\text { of an insurance group, using a } \\
\text { common client base, implement } \\
\text { insurance policies }\end{array}$ & $\begin{array}{l}\text { The bank, using the same client base } \\
\text { with the insurance company, sells } \\
\text { insurance policies (based on agency } \\
\text { agreement) and provides banking } \\
\text { services }\end{array}$ & $\begin{array}{l}\text { The medical institution, using the same } \\
\text { client base with the insurance company, } \\
\text { implements insurance policies (based on } \\
\text { agency agreement) and provides medical } \\
\text { services }\end{array}$ \\
\hline $\begin{array}{l}\text { IT and IT } \\
\text { platforms }\end{array}$ & $\begin{array}{l}\text { Each member of the insurance } \\
\text { group places on its website } \\
\text { (platform) in the Internet } \\
\text { information about its services, } \\
\text { as well as about the services of } \\
\text { its partner }\end{array}$ & $\begin{array}{l}\text { Each participant of the convergence - a } \\
\text { bank and an insurance company, places } \\
\text { on its website (platform) in the Internet } \\
\text { information about its services, as well } \\
\text { as about the services of its partner }\end{array}$ & $\begin{array}{l}\text { Each convergence participant - a medical } \\
\text { institution and an insurance company, } \\
\text { places information about its services, as } \\
\text { well as those of a partner, on its website } \\
\text { in the Internet }\end{array}$ \\
\hline $\begin{array}{l}\text { IT, IT platforms } \\
\text { and IT networks }\end{array}$ & $\begin{array}{l}\text { Each member of insurance group } \\
\text { posts on its website (platform) in } \\
\text { the Internet information about } \\
\text { its services, as well as about the } \\
\text { services of its partner; due to the } \\
\text { networks connecting the partner } \\
\text { platforms, it makes it possible } \\
\text { to instantly go to the partner's } \\
\text { website; provides the ability to } \\
\text { issue and pay for an insurance } \\
\text { policy online }\end{array}$ & $\begin{array}{l}\text { Each convergence participant - a bank } \\
\text { and an insurance company, places on } \\
\text { its website (platform) in the Internet } \\
\text { information about its services, as well } \\
\text { as about the services of its partner; } \\
\text { due to the networks connecting the } \\
\text { partner platforms, it makes it possible } \\
\text { to instantly go to the partner's website; } \\
\text { provides an opportunity to register } \\
\text { and pay for any service provided by } \\
\text { partners online }\end{array}$ & $\begin{array}{l}\text { Each convergence participants - a } \\
\text { medical institution and an insurance } \\
\text { company, places on its website (platform) } \\
\text { in the Internet information about its } \\
\text { services, as well as about the services of } \\
\text { its partner; } \\
\text { due to the networks connecting the } \\
\text { partner platforms, it makes it possible } \\
\text { to instantly go to the partner's website; } \\
\text { provides an opportunity to register and } \\
\text { pay for any service provided by partners } \\
\text { online }\end{array}$ \\
\hline
\end{tabular}

Table A2. Additional opportunities provided by the third stage digitalization product (IT, IT platforms and networks)

\begin{tabular}{|c|c|c|}
\hline $\begin{array}{l}\text { Additional } \\
\text { possibilities }\end{array}$ & $\begin{array}{l}\text { The insurance company } \\
\text { providing the possibility }\end{array}$ & Meaning of the possibility \\
\hline $\begin{array}{l}\text { 1. Purchasing of policies } \\
\text { and their payment online }\end{array}$ & Insurance company Adonis & $\begin{array}{l}\text { This use of the site illustrates the combination of such business } \\
\text { processes of the insurer as informing about insurance services, } \\
\text { concluding an insurance contract and ensuring cash flows under the } \\
\text { contract. This is possible by combining the insurer's platform (its } \\
\text { website) and the payment terminal (platform) through which the } \\
\text { insurance premium is paid. }\end{array}$ \\
\hline $\begin{array}{l}\text { 2. Opening of personal } \\
\text { accounts through which } \\
\text { the policyholder can } \\
\text { interact with the insurer } \\
\text { and the intermediary } \\
\text { (broker, agent) with the } \\
\text { insurer }\end{array}$ & $\begin{array}{l}\text { Ingosstrakh Insurance Company, } \\
\text { Rosgosstrakh Insurance Company, } \\
\text { Insurance company Alfa Insurance } \\
\text { Rosgosstrakh }\end{array}$ & $\begin{array}{l}\text { Personal account of the agent of Ingosstrakh, created using the } \\
\text { Ingogate system, Virtu Systems - a program for the work of an agent } \\
\text { of the insurance company Rosgosstrakh, the personal account of } \\
\text { the insured in the insurance company Alfa Insurance, Rosgosstrakh's } \\
\text { platform Agentology, which makes it possible to attract agents for } \\
\text { online sales of insurance policies. }\end{array}$ \\
\hline \multicolumn{3}{|c|}{ 3. Provision of additional services to policyholders by partners of the insurance company in a joint business } \\
\hline $\begin{array}{l}\text { 3.1. From its own sector } \\
\text { of the economy common } \\
\text { to all participants } \\
\text { in intra-segment } \\
\text { convergence }\end{array}$ & $\begin{array}{l}\text { The insurance company } \\
\text { Alfastrakhovanie enables a client } \\
\text { to receive a life insurance service } \\
\text { from the insurance company } \\
\text { Alfastrokhovanie Zhizn }\end{array}$ & $\begin{array}{l}\text { This is made possible through the interaction carried out through } \\
\text { networks that connect the sites (IT platforms) of these companies }\end{array}$ \\
\hline $\begin{array}{l}\text { 3.2. From different } \\
\text { segments of the } \\
\text { economy common } \\
\text { to all participants } \\
\text { in intersegment } \\
\text { convergence }\end{array}$ & $\begin{array}{l}\text { Sovkombankstrakhovanie company, } \\
\text { marketplace of the Central Bank } \\
\text { of the Russian Federation and } \\
\text { financial platform of JSC Financial } \\
\text { Marketplace Sravni.ru }\end{array}$ & $\begin{array}{l}\text { The company Sovkombankstrakhovanie. In addition to insurance } \\
\text { services, the joint business allows its client through the website } \\
\text { of the insurance company to obtain a bank card Halva issued } \\
\text { by Sovkombank. Another example of using the most complex } \\
\text { digitalization product by financial market entities is the participation } \\
\text { of insurance companies along with other financial organizations in } \\
\text { financial platforms. These technologies of insurance companies open } \\
\text { up opportunities for the sales of products such as MTPL insurance, } \\
\text { travel insurance, mortgage insurance, real estate insurance, etc. }\end{array}$ \\
\hline
\end{tabular}


Table A2 (cont.). Additional opportunities provided by the third stage digitalization product (IT, IT platforms and networks)

\begin{tabular}{|c|c|c|}
\hline $\begin{array}{l}\text { Additional } \\
\text { possibilities }\end{array}$ & $\begin{array}{l}\text { The insurance company } \\
\text { providing the possibility }\end{array}$ & Meaning of the possibility \\
\hline $\begin{array}{l}\text { 3.3. From different } \\
\text { segments and sectors } \\
\text { of the economy for } \\
\text { participants in cross- } \\
\text { sectoral convergence }\end{array}$ & $\begin{array}{l}\text { Insurance companies Gaide and } \\
\text { Capital-Policy, insurance company } \\
\text { Rosgosstrakh, Sberbank Insurance }\end{array}$ & $\begin{array}{l}\text { Insurance companies provide additional opportunities for their } \\
\text { clients, in addition to the insurance services proper, to receive medical } \\
\text { services provided by their partners - medical centers. Another model } \\
\text { for organizing a joint business allows the insured persons to switch, } \\
\text { using digitalization products, to the mobile applications "My honey } \\
\text { service" and "My auto service" and receive additional services related } \\
\text { to these types of insurance. Participation in the financial ecosystem } \\
\text { "Sber" enables the Sberbank Insurance clients, in addition to receiving } \\
\text { insurance services through its website, to access almost all segments } \\
\text { of the economy - logistics, leisure and banking }\end{array}$ \\
\hline $\begin{array}{l}\text { 4. Full customer service } \\
\text { through websites during } \\
\text { the term of the insurance } \\
\text { contract - from the } \\
\text { moment of its conclusion } \\
\text { until the end }\end{array}$ & Insurance company Mango & $\begin{array}{l}\text { Insurance company Mango, operating completely in digital form } \\
\text { without offices and providing services "by subscription" - for the } \\
\text { period of one month }\end{array}$ \\
\hline
\end{tabular}

